\title{
Tectonic processes in Svalbard tide-water glacier surges: evidence from structural glaciology
}

\author{
RICHARD HODGKINS \\ Scott Polar Research Institute, University of Cambridge, Cambridge CB2 1ER, England \\ JULIAN A. DOWDESWELL \\ Centre for Glaciology, Institute of Earth Studies, University of Wales, Aberystwyth, Dyfed ST23 3DB, Wales
}

\begin{abstract}
The tectonic effects of a glacier surge differ from those of steady state because flow is driven by longitudinal stresses rather than shear stresses. The orientations of recently formed crevasses, indicating the directions of the principal stresses, have been used to investigate tectonic processes in glacier surges recorded by repeat aerial photography. Long-term, large-magnitude shifts in stress regime are demonstrated, as are short-term propagation features. Two types of tide-water glacier advance are identified, depending on the position of the surge front relative to a low effective-pressure zone at the glacier terminus.
\end{abstract}

\section{INTRODUGTION}

Bulk tectonics in a steady-state glacier are described by a pattern of velocity acceleration in the accumulation area towards a maximum at the equilibrium line, yielding a positive velocity gradient (strain rate), indicating extension; then deceleration towards the terminus, yielding a negative velocity gradient, indicating compression (Nye, 1952). A clear exception to this pattern occurs during the active phase of a surge cycle. Raymond and others (1987) discussed the propagation of a surge front during the 1982-83 surge of Variegated Glacier, Alaska. The front developed in the upper glacier and propagated down-glacier into stagnant ice; it was expressed at the surface as a steep topographic ramp, 1-2 km long, within which emergent velocities and longitudinally compressive strain rates were greatly enhanced by comparison with quiescent flow conditions. Three dynamic zones were defined: stagnant (velocities $<0.1 \mathrm{~m} \mathrm{~d}^{-1}$ ), surge front (a transitional zone) and fully surging (velocities $>20 \mathrm{~m} \mathrm{~d}^{-1}$ ). The surge front propagated with a mean velocity of approximately $40 \mathrm{~m} \mathrm{~d}^{-1}$, roughly double that of the surging ice. Sharp and others (1988) interpreted the same surge in tectonic terms as the propagation of a strain wave, and defined three tectonic zones. Furthest up-glacier was a zone of extension tectonics which remained above the velocity peak throughout the active phase and experienced continuous and cumulative elongation, characterized by transverse crevassing. Further down-glacier was a zone of superimposed extension and compression tectonics, through which the velocity peak had propagated; intersecting transverse and longitudinal crevasses were present. Furthest down-glacier was a zone of compression tectonics, which remained below the velocity peak and underwent continuous and cumulative compression, its characteristic structures being longitudinal crevasses.

The aim of this paper is to assess the tectonic effects of glacier surges in the Norwegian High Arctic archipelago of Svalbard (Fig. 1a and b). Structural data are obtained from repeat aerial photography. Tide-water glaciers only are selected because they are of sufficient size to be susceptible to the analysis described below; moreover, the examples in this paper represent the complete population with repeat photographs during the active phase. The discussion focuses on mechanisms of advance of tide-water glacier termini.

\section{DATA SOURGES AND METHODS}

\section{Grevasse formation and tectonic regime}

Crevasses form where at least one of the principal stresses at the surface of a glacier is extending and in excess of the tensile strength of glacier ice (Paterson, 1981); they are orientated perpendicularly to the direction of the principal extending stress (Nye, 1952; Meier, 1958). Analysis of crevasse orientation can be a useful means of interpreting tectonic regimes in glaciers at a bulk scale. For the purposes of this paper, the tectonic regime of a glacier will be defined by the direction of the principal stress at the surface. When longitudinally extending (positive), it will give rise to transverse crevasses, and when longitudinally compressive (negative), longitudinal crevasses will result. The interpretation of crevasse patterns near the centre line is problematic when crevasses have been advected away from their region of formation and deformed (Hambrey and Müller, 1978); 


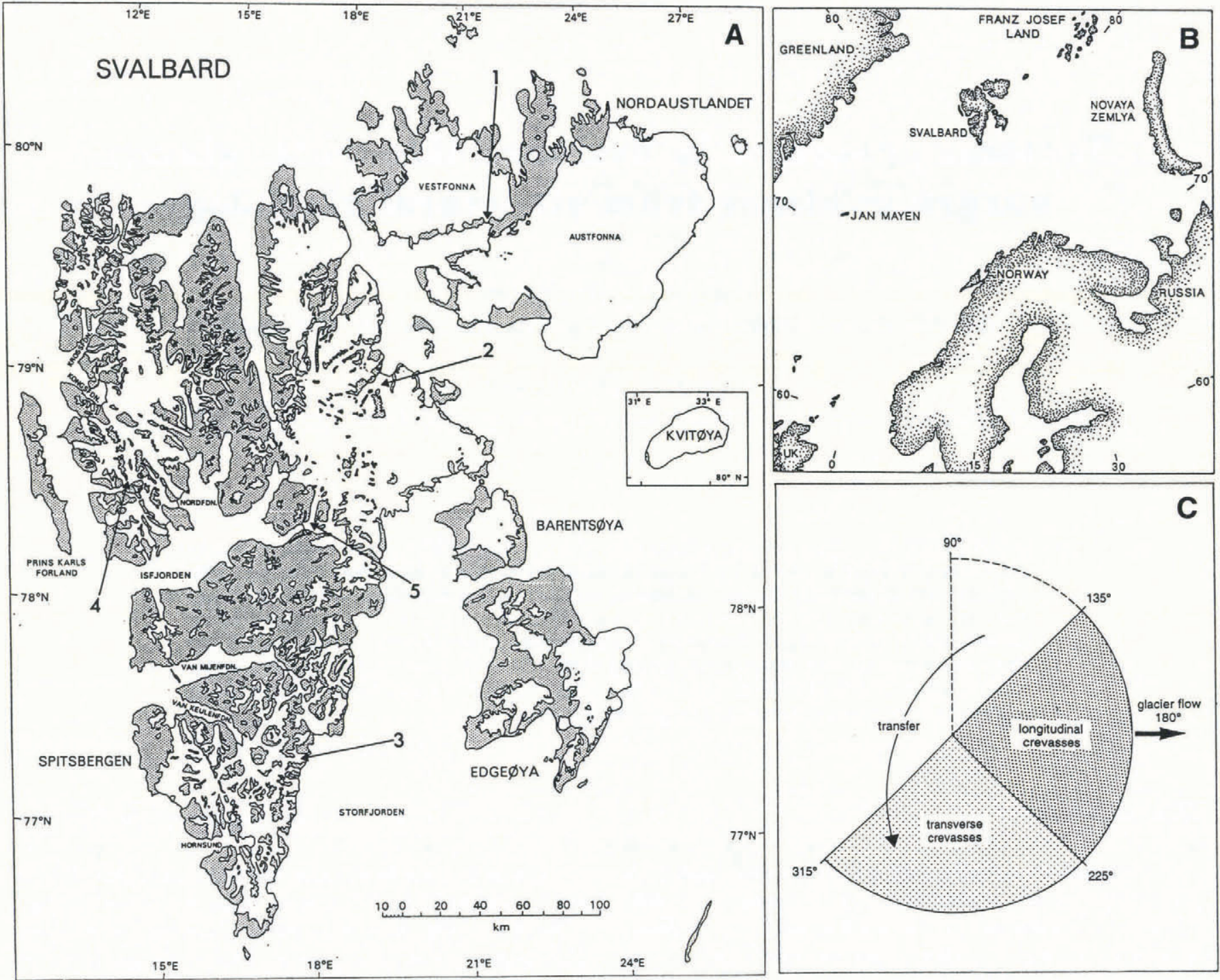

Fig. 1. a. Map of Svalbard showing locations of glaciers mentioned in the text. Glacierized areas are shown in white and non-glacierized areas are shaded. Glaciers are: 1, Bodleybreen; 2, Hinlopenbreen; 3, Jemelianovbreen; 4, Osbornebreen; 5, Tunabreen. b. Location of Svalbard in the European Arctic. c. Notation system for measuring crevasse orientations.

however, in active-phase surge-type glaciers, crevasses are likely to be recently formed, and therefore to reflect closely the prevailing tectonic regime.

\section{Obtaining structural data}

The orientation of crevasses can be measured on structural maps or vertical aerial photographs of glaciers. In this paper, crevasse orientations have been recorded digitally within a linear grid aligned along the centre line of the glacier. Within each grid square, which varies in size from 0.25 to $1.0 \mathrm{~km}^{2}$, according to the size of the glacier, a mean value is obtained for the orientation of crevasses. The measuring procedure assigns crevasses to one of two $90^{\circ}$ quadrants according to their orientation relative to the direction of ice flow, where $180^{\circ}$ is the down-glacier direction: $135-225^{\circ}$ longitudinal, $225-315^{\circ}$ transverse (Fig. 1c). This procedure ensures that a series of transverse crevasses always has a mean that tends to $270^{\circ}$, rather than the $180^{\circ}$ which would obtain if the $90-135^{\circ}$ sector were included; longitudinal crevasses tend towards the correct $180^{\circ}$ mean. In this way, it is ensured that oblique crevasses are assigned to the correct sector. The standard deviation of crevasse orientations for each grid square has also been recorded. When both longitudinal and transverse crevasses are present in the same grid square, there is a relatively high standard deviation; when one set or the other dominates, the standard deviation is relatively low.

Two simple statistical tests are used to describe the data; both are non-parametric and are applicable to data measured on, or in this case converted to, an ordinal scale. The Spearman rank correlation coefficient, $R$, is a measure of the correspondence between two data sets, and is found from:

$$
R=1-\frac{6 \Sigma d^{2}}{n^{3}-n}
$$

where $d$ is the difference in rank for each value and $n$ is the number of ranked values (data sets are ranked individually). A value of 1.0 implies a perfect positive relationship, -1.0 a perfect inverse relationship, and 0.0 no relationship. The Mann-Whitney statistic, $U$, is a measure of the difference between two data sets, and is 
found from:

$$
\begin{aligned}
& U_{x}=n_{x} n_{y}+\frac{n_{x}\left(n_{x}+1\right)}{2}-\Sigma r_{x} \\
& U_{y}=n_{x} n_{y}+\frac{n_{y}\left(n_{y}+1\right)}{2}-\Sigma r_{y}
\end{aligned}
$$

where $n$ is the number of values in data sets $x$ and $y$, and $r$ is the rank for each value (data sets are ranked together); for a non-directional test, the smaller statistic is stated. A low value of $U$ indicates a large difference, and vice versa. Both tests are useful for data obtained from measurements of natural systems, because they do not rely on any assumptions about the population distributions of the variables. Because the values used in this paper are means of the orientations of all the crevasses in the stated
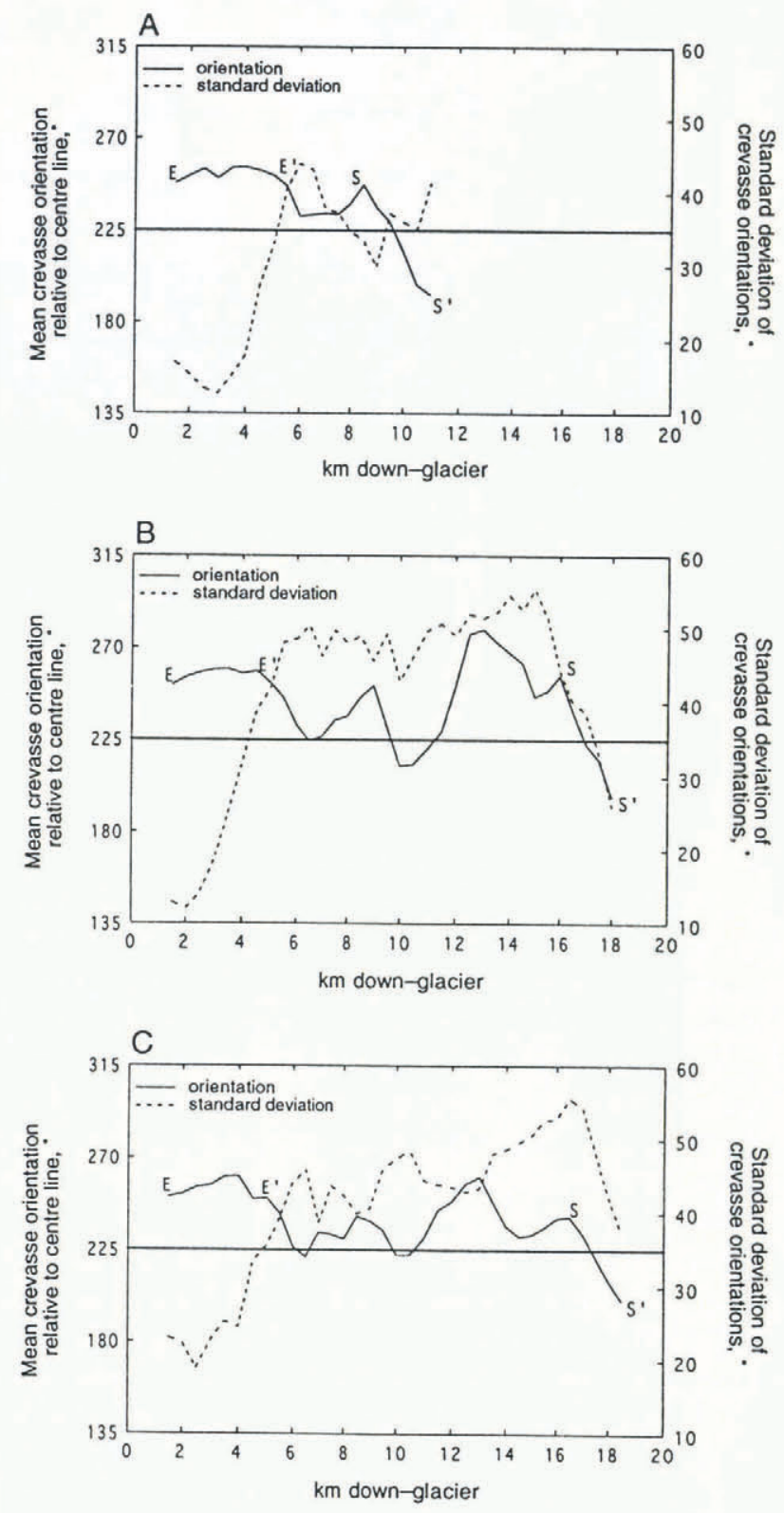

Fig. 2. Crevasse orientation and standard deviation at Variegated Glacier, Alaska, in (a) July 1982 (first phase of the surge), (b) June 1983 (second phase of the surge), and (c) August 1983 (second phase of the surge). The terminus was at $20.0 \mathrm{~km}$ in each case, but ice was only activated up to $18.5 \mathrm{~km}$ during the surge. $E-E^{\prime}$ marks the zone of extension tectonics, $E^{\prime}-S$ the zone of superimposed extension and compression tectonics (Sharp and others, 1988 ) and $S-S^{\prime}$ the surge front. interval, they are not regarded as samples, so significance levels are not stated.

\section{Testing the method}

Curves of mean crevasse orientation and standard deviation are shown for Variegated Glacier in July 1982, June 1983 and August 1983 (Fig. 2). These were obtained, using the method described above, from structural maps drawn from vertical aerial photographs, presented in Lawson (1989). In each period the surge front $\left(\mathrm{S}-\mathrm{S}^{\prime}\right)$ can be clearly identified as a steep section on the crevasse-orientation curve, falling from a peak of extension at its up-glacier edge to one of compression at its down-glacier edge. The leading edge of this section is marked by a sharp increase in the standard deviation of the mean crevasse orientations, additional evidence that this is a transitional zone. The down-glacier limits of the first phase of surge activity, at around $11 \mathrm{~km}$, and of the second phase, at around $18.5 \mathrm{~km}$, agree with field observations (Kamb and others, 1985). Up-glacier of the surge front is the zone of superimposed compression and extension tectonics $\left(E^{\prime}-S\right)$, which is represented by high standard deviations of crevasse orientation, reflecting the overlaying of contrasting tectonic regimes; this section lengthens as the surge front propagates downglacier, and behind it is the zone of extension tectonics $\left(\mathrm{E}-\mathrm{E}^{\prime}\right)$. The method therefore appears to offer a suitable representation of tectonic regimes.

\section{EVIDENCE FROM SVALBARD SURGE-TYPE GLACIERS}

\section{Glaciology and glacier surges in Svalbard, Norwegian High Arctic}

Almost 80 glacier surges have been recorded in Svalbard since the middle of the 19th century (Liestøl, 1993). The glacial environment of Svalbard differs in some important respects from the temperate, high-accumulation southeast Alaskan environment. Mass-balance gradients are typically low: values from Pelto and others (1990) are $95.2 \mathrm{~cm} / 100 \mathrm{~m}$ for Alaskan glaciers $\left(58-61^{\circ} \mathrm{N}\right)$ but only $42.6 \mathrm{~cm} / 100 \mathrm{~m}$ for Svalbard glaciers $\left(78-79^{\circ} \mathrm{N}\right)$. Moreover, significant parts of Svalbard glaciers are at temperatures below the pressure-melting point: typically, ice is cold in the ablation area and temperate in parts of the accumulation area (e.g. Hagen and others, 1991; Ødegård and others, 1992). Svalbard glacier surges themselves are distinctive in some respects. The duration of the surge cycle is long in Svalbard by comparison with studied surge-type glaciers in other regions, typical values being $3-10$ years for the active phase and 50-500 years for the quiescent phase; in addition, surge termination appears to occur gradually rather than abruptly (Dowdeswell and others, 1991). The method described above has been applied to three surgetype glaciers in Svalbard, with repeat aerial photography by the Norsk Polarinstitutt, Oslo.

\section{Bodleybreen, Gustav V Land, Nordaustlandet}

Bodleybreen (1 in Fig. 1a; length $16 \mathrm{~km}$, area $87 \mathrm{~km}^{2}$ ) is 

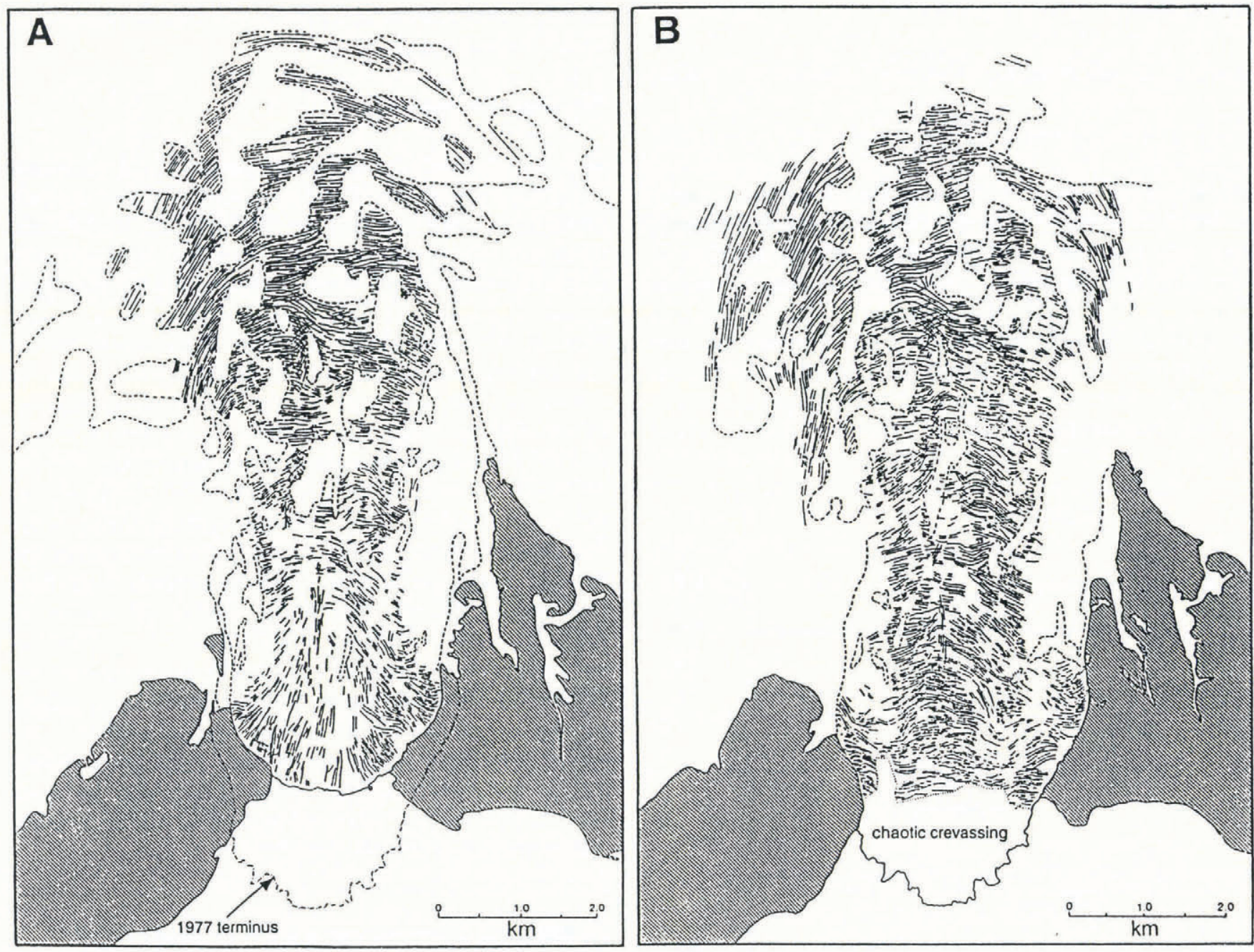

Fig. 3. Crevasse-pattern maps of Bodleybreen in (a) 1970, (b) 1977.

an ice-cap outlet glacier which flows as an ice stream in its upper reaches, but is constricted by bedrock near its tidewater terminus. Dowdeswell and Collin (1990) measured a maximum centre-line velocity of $197 \mathrm{~m} \mathrm{a}^{-1}$ between 1970 and 1971 , declining to $20-50 \mathrm{~m} \mathrm{a}^{-1}$ near the margins. A surge was initiated on Bodleybreen during or soon after 1973 and continued for approximately 7 years (Dowdeswell and others, 1991). The terminus advanced at a mean rate of $220 \mathrm{~m} \mathrm{a}^{-1}$ up to 1977 and at $510 \mathrm{~m} \mathrm{a}^{-1}$ up to 1981 . There was a $10-60 \mathrm{~m}$ thickening in the lower glacier and a $10-15 \mathrm{~m}$ thinning in the upper glacier over the period 1970-77 (Dowdeswell and Collin, 1990).

The interval between air-photograph acquisitions at Bodleybreen is long (1970-77), and the glacier displays a marked change in tectonic regime (Fig. 3). Prior to the surge, in 1970, the glacier was in strong compression below $13.5 \mathrm{~km}$; above this point there was extension, increasing slightly up-glacier, consistent with the formation of the ice stream (Fig. 4a). The pattern was largely unchanged up-glacier of $13.5 \mathrm{~km}$ in 1977 (Fig. 4b): the data from this part of the glacier for these 2 years give an $R$ statistic of 0.69 . Down-glacier of $13.5 \mathrm{~km}$, however, there was a pronounced shift to extension: the mean orientation of crevasses in this section was $176^{\circ}$ in 1970 but was $253^{\circ}$ in 1977 . This part of the glacier gives an $R$ statistic of -0.77 . Similarly, data up-glacier of $13.5 \mathrm{~km}$ give a $U$ statistic of 88 , whereas down-glacier of $13.5 \mathrm{~km}$ the statistic is 36 , indicating a much larger difference between the 2 years below this point than above it. Peak crevasse-orientation standard deviation in both years is up-glacier of $13.5 \mathrm{~km}$; this may be associated with an area of converging flow where the drainage basin narrows. Crevasse-orientation standard deviations in both years are low both above and below this area, reflecting the uniformity of the tectonic regimes in each part of the glacier.

Peak crevasse density in 1977 was located near the head of the surging section at $12.0 \mathrm{~km}$, with a second peak again nearer the terminus at $15.0 \mathrm{~km}$ (Fig. 4c). The lowermost $1.1 \mathrm{~km}$ of the glacier were chaotically crevassed in 1977; this section has been excluded from the analysis as it could not be measured in a meaningful way. The length of the measured profile is virtually unchanged, however, because the terminus had advanced $1.3 \mathrm{~km}$. There was a mean increase in crevasse density of $217 \%$ down-glacier of $13.5 \mathrm{~km}$. Comparison of crevasse densities for both years above this point gives an $R$ statistic of 0.68 , whereas below this point this statistic is only 0.28. Similarly, data up-glacier of this point for both years give a $U$ statistic of 80 , whereas below it the statistic is 36 , again indicating a much greater difference between the 2 years below $13.5 \mathrm{~km}$. 

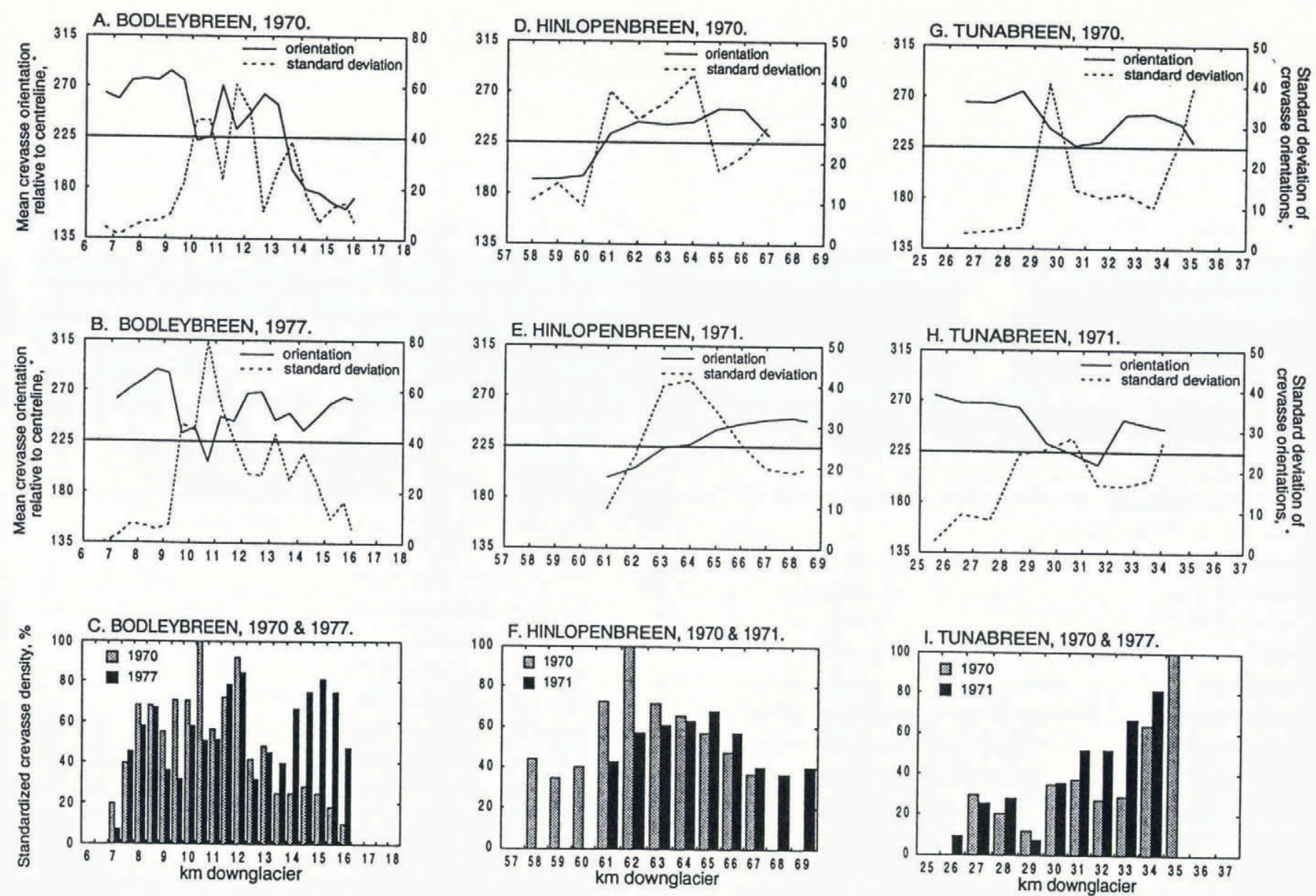

Fig. 4. (a) Crevasse orientation and standard deviation in 1970, and (b) 1977, and (c) crevasse density in 1970 and 1977 at Bodleybreen, Svalbard. (The terminus was at $16.0 \mathrm{~km}$ in 1970 and there was no chaotic crevassing; there was chaotic crevassing from $16.2 \mathrm{~km}$ to the terminus at $17.3 \mathrm{~km}$ in 1977.) (d) Crevasse orientation and standard deviation in 1970, and (e) 1971, and (f) crevasse density in 1970 and 1971 at Hinlopenbreen, Svalbard. (There was chaotic crevassing from $67.0 \mathrm{~km}$ to the terminus at $68.0 \mathrm{~km}$ in 1970 , and from $68.5 \mathrm{~km}$ to the terminus at $69.75 \mathrm{~km}$ in 1971 .) (g) Crevasse orientation and standard deviation in 1970, and ( h) 1971, and (i) crevasse density in 1970 and 1971 at Tunabreen, Svalbard. (The terminus was at $35.0 \mathrm{~km}$ in 1970 and there was no chaotic crevassing; there was chaotic crevassing from $34.1 \mathrm{~km}$ to the terminus at $35.2 \mathrm{~km}$ in 1971.) Crevasse densities have been standardized by expressing values as percentages of the highest value in either year.

\section{Hinlopenbreen, Olav V Land, northeast Spitsbergen}

Hinlopenbreen (2 in Fig. 1a; length $68 \mathrm{~km}$, area 1250 $\mathrm{km}^{2}$ ) is an ice-cap outlet glacier with a tide-water terminus. A surge began during or possibly before 1968 and continued for at least 4 years (Dowdeswell and others, 1991). Intense crevassing from the uppermost tributaries to the terminus indicated that the entire glacier was taking part in the surge. From August 1969 to August 1970 the glacier had a mean velocity of $16 \mathrm{~m} \mathrm{~d}^{-1}$ (Liestøl, 1972); between August 1970 and August 1971 the terminus advanced by up to $3 \mathrm{~km}$, with a mean velocity of $14 \mathrm{~m} \mathrm{~d}^{-1}$, although up to $2 \mathrm{~km} \mathrm{a}^{-1}$ of advance across the glacier front was lost by calving, with icebergs of up to $100 \mathrm{~m}$ in length observed (Liestøl, 1973).

The interval between air-photograph acquisitions at Hinlopenbreen (1970-71) is much shorter than at Bodleybreen, and the glacier was in the active phase in both years, so a finer resolution of changes is possible. Between 1970 and 1971 the terminus of the glacier advanced $1.75 \mathrm{~km}$, and the extent of chaotic crevassing at the terminus increased from 1 to $1.25 \mathrm{~km}$. The apparent reduction in the density of crevasses in 1971 (Fig. 4f) is a function of the development of very large chasms (up to $50 \mathrm{~m}$ wide) in the centre of the glacier. The zone of compression up-glacier of about $61 \mathrm{~km}$ is unexpected (Fig. 4d). However, inspection of aerial photographs from both years shows that ice appears to be streaming around this feature, and that ice up to $7 \mathrm{~km}$ ahead of it is fully surging. It is therefore unlikely that this represents a compression front, and it is concluded that this feature is more likely to be related to bed topography. Nevertheless, peak extension appears to propagate $3 \mathrm{~km}$ down-glacier over the interval (Fig. 4e). A wave of extension propagating through the glacier might therefore be inferred. Similarly, peak crevasse density seems to propagate $3.5 \mathrm{~km}$ down-glacier, but this may not accurately reflect the true situation because of the changing sizes of crevasses.

The crevasse-orientation data from the 2 years give an $R$ statistic of 0.11 , which indicates an extremely weak correlation; however, if the 1971 data are translated $3 \mathrm{~km}$ up-glacier (the distance the extension peak travelled) and the test repeated, an $R$ statistic of 0.92 , a very good correlation, is obtained. (The $U$ statistic is less helpful in this case, as it ranks all values from both data sets 
together, and therefore does not distinguish the translated data.) The propagating feature therefore appears to be a more-or-less fixed spatial pattern, at least at the scale resolved here. The pattern of crevasse-orientation standard deviations is broadly peaked between 60 and $65 \mathrm{~km}$ in both years. The sharp rise in standard deviations between 60 and $61 \mathrm{~km}$ may be related to the convergence of ice that has streamed around the possible compression feature discussed above, rather than being related to the surge motion.

\section{Tunabreen, Sabine Land, eastern Spitsbergen}

Tunabreen ( 5 in Fig. 1a; length $35 \mathrm{~km}$, area $203 \mathrm{~km}^{2}$ ) is an ice-cap outlet glacier with a tide-water terminus. It is one of only three Svalbard glaciers known to have surged twice, doing so around 1930 and 1970 (Liestøl, 1993); the second surge is examined here. The glacier was photographed in 1966 and was quiescent, but the surge was well under way when it was photographed again in 1970; and in the spring of 1971 the terminus was still advancing at around $1 \mathrm{~m} \mathrm{~d}^{-1}$ (Liestøl, 1972). By August 1971, the terminus had advanced $150-550 \mathrm{~m}$ by comparison with its position in July 1970, giving mean rates of between 0.4 and $1.4 \mathrm{~m} \mathrm{~d}^{-1}$. The maximum displacement of the terminus from the pre-surge position in 1966 was approximately $1.5 \mathrm{~km}$.

The changes in tectonic regime at Tunabreen between 1970 and 1971 are small by comparison with Bodleybreen and Hinlopenbreen. In fact, the crevasse-orientation and density data from the 2 years, without any displacement adjustment, give $R$ statistics of 0.92 and 0.80 , respectively, both strong positive correlations. Above $29 \mathrm{~km}$ is a section of strong, uniform extension with a mean crevasse orientation close to $270^{\circ}$ and a standard deviation of less than $10^{\circ}$ in both years (Fig. $4 \mathrm{~g}$ and $\mathrm{h}$ ). Immediately below this is a compression front, in which the mean orientation of crevasses falls from $275^{\circ}$ to $227^{\circ}$ in the space of $2 \mathrm{~km}$ in 1970 , giving a gradient of $24^{\circ} \mathrm{km}^{-1}$; in 1971 , the up-glacier edge of this front had little changed, but the down-glacier edge had propagated approximately $1 \mathrm{~km}$ down-glacier, so that the fall is from $264^{\circ}$ to $213^{\circ}$ in $3 \mathrm{~km}$, giving a gradient of $17^{\circ} \mathrm{km}^{-1}$. This front is associated with a pronounced crevasse-orientation standard-deviation peak, over $40^{\circ}$ in 1970 , affirming its function as a transitional zone.

Down-glacier of about $32.5 \mathrm{~km}$ in both years is a second zone of extension, which leads into a chaotically crevassed area at the terminus (which has not been plotted). The approach to the chaotically crevassed zone is marked by a decrease in the mean crevasse orientation (since both longitudinal and transverse crevasses are included) and a sharp increase in the standard deviation of crevasse orientations. In 1971, the lowermost $1.1 \mathrm{~km}$ of the glacier were chaotically crevassed, while the terminus had made a $0.2 \mathrm{~km}$ advance. Otherwise, the most pronounced change in crevasse density is between 30 and $34 \mathrm{~km}$, where the mean density is $61 \%$ greater in 1971 (Fig. 4i). The crevasse-density data for the 2 years give a $U$ statistic in this part of the glacier of 14 , a much larger difference than for the glacier as a whole, which has a $U$ statistic of 61 .

\section{DISCUSSION}

\section{Conditions at tide-water glacier termini}

The continuous fast flow of tide-water glaciers has in common with the periodic fast flow of surge-type glaciers the fact that it is driven by longitudinal stresses in addition to shear stresses. Where a glacier terminus is below sea level, the effective pressure $p_{\mathrm{e}}$ is reduced, because basal water pressures $p_{\mathrm{w}}$ increase relative to the ice-overburden pressure $p_{\mathrm{i}}$ and fast flow is sustained through the terminus in the absence of longitudinal compression. Meier and Post (1987) expressed this as follows, assuming infinite hydraulic conductivity in the basal water system:

$$
p_{\mathrm{e}}=p_{\mathrm{i}}-p_{\mathrm{w}}=\rho_{\mathrm{i}} g h+\rho_{\mathrm{w}} g z_{\mathrm{b}}-g h_{\mathrm{w}}\left(\rho_{\mathrm{w}}^{\prime}-\rho_{\mathrm{w}}\right)
$$

where $z_{\mathrm{b}}$ is the elevation of the bed relative to sea level, $\rho_{\mathrm{w}}$ is the density of fresh water, $\rho_{\mathrm{w}}^{\prime}$ is the density of sea water and $h_{\mathrm{w}}$ is the water depth at the terminus; the second term on the righthand side represents the water pressure at the base of a fresh-water body of depth $-z_{\mathrm{b}}$ and this is corrected for the increased density of sea water at the terminus by the third term.

The compression front was a key feature in the Variegated Glacier surge, the advance of rapid motion being controlled largely by conditions within that front zone (Pfeffer, 1987). It was noted above that compression is not usually encountered at tide-water glacier termini, although a compression front was observed on Tunabreen. However, this situation may not be as contradictory as it appears at first sight. The lower edge of the Tunabreen front was about $3.6 \mathrm{~km}$ above the terminus in 1971. It is likely that this is well above the low effectivepressure zone: radio-echo sounding has shown that the bed of Von Postbreen, a tide-water glacier immediately adjacent to Tunabreen, is still above sea level at $1.2 \mathrm{~km}$ from the terminus (Dowdeswell, 1984). Similarly, the mean thickness of Tunabreen is only $202 \mathrm{~m}$ (Hagen and others, 1993) so it is unlikely that a deep trough below sea level will exist far up-glacier. Hence, for much of the glacier's $35 \mathrm{~km}$ length, a surge-related zone of enhanced longitudinal compression might exist.

\section{Terminus advance during tide-water glacier surges}

It is notable that the Tunabreen terminus is advancing, although the compression front (and hence the surging ice) has not reached it. This is consistent with the abovedescribed behaviour of the tide-water terminus. Due to the absence of longitudinal compression there, ice in the low effective-pressure zone is, in effect, pushed along by the surging ice up-glacier. The compression front itself is eliminated when it enters the low effective-pressure zone: the Tunabreen compression front becomes less steep as it approaches the glacier terminus, and no compression fronts were observed at Bodleybreen and Hinlopenbreen. Advance of the terminus may then be very rapid as the surging ice flows through the terminal zone in the absence of longitudinal compression. A simple calculation shows how likely a front is to reach the terminus. Raymond and 

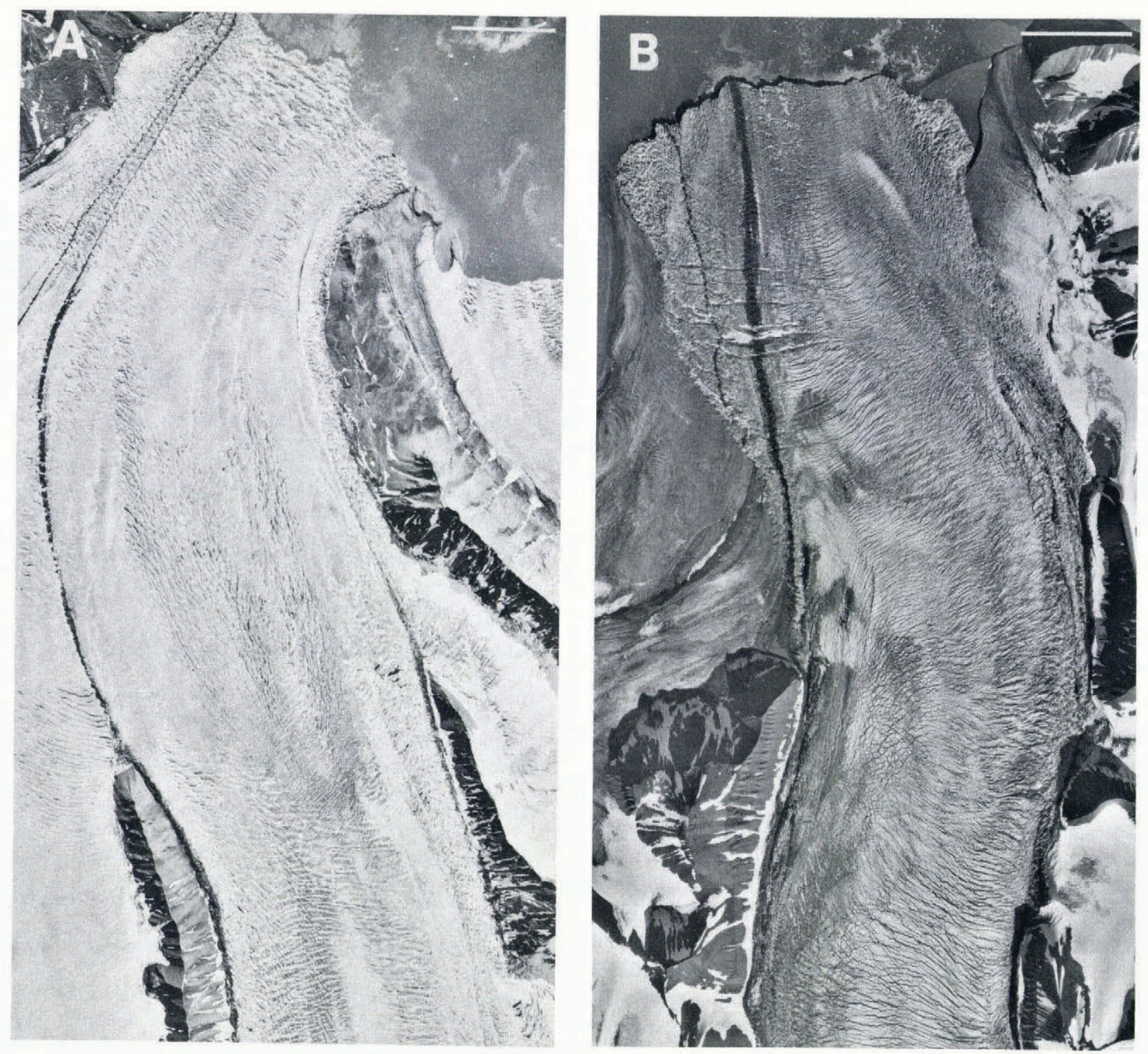

Fig. 5. a. Steady terminus advance $\left(450 \mathrm{ma}^{-1}\right)$ at Osbornebreen, Oscar II Land, Svalbard (Norsk Polarinstitutt photograph S90 3485). The surge front, the area of longitudinal crevassing in the centre of the photograph, has not yet reached the low effective-pressure zone at the tide-water terminus, and between these two areas the glacier is relatively uncrevassed. b. Rapid terminus advance $\left(1000 \mathrm{ma}^{-1}\right)$ at Jemelianovbreen, Torell Land, Svalbard (Norsk Polarinstitutt photograph S71 6036). The surge front has reached the low effective-pressure zone at the tide-water terminus, and has been eliminated: the glacier is intensely transversely crevassed throughout. Both glaciers are located in Figure 1a; the scale bar in the top righthand corner of each photograph represents a distance of $1 \mathrm{~km}$.

others (1987) modelled the propagation rate $w$ of a surge front from volume conservation as:

$$
w \approx u_{2} h_{2} /\left(h_{2}-h_{1}\right)
$$

where $u$ is horizontal velocity and $h$ is ice thickness; subscripts 1 and 2 denote the non-surging and surging zones, respectively. Calculation for Bodleybreen, for which the thickness changes are known, gives a propagation speed of $6.5 \mathrm{~m} \mathrm{~d}^{-1}$; this would have been sufficient to have travelled almost $9.5 \mathrm{~km}$ by 1977 , easily far enough to have reached the terminus.

It is therefore suggested that there are two types of surge-related tide-water glacier-terminus advance: a relatively steady "push" prior to the surge front entering the low $p_{\mathrm{e}}$ zone (e.g. Tunabreen, advancing at $320 \mathrm{~m} \mathrm{a}^{-1}$ ) and a more rapid "rush" afterwards (e.g. Hinlopenbreen, advancing at $\left.1200 \mathrm{~m} \mathrm{a}^{-1}\right)$. These types of advance can be illustrated by two further examples from Svalbard (Fig. 5). The absence of longitudinal compression in this low $p_{\mathrm{e}}$ region at the terminus may also account for the uniform extension tectonics (with low crevasse-orientation standard deviation) observed in the Svalbard examples here, that is, for the subdued superimposed extension and compression tectonics zone (Sharp and others, 1988).

\section{Contrast with other advancing tide-water glaciers}

Many of the tide-water glaciers of Alaska are known to be in a cycle (unrelated to climatic forcing), with a phase of steady advance on the order of a millennium, followed by a phase of catastrophic retreat on the order of decades (Meier and Post, 1987; Sturm and others, 1991). No tide- 
water glacier in Svalbard has been identified as being in either phase of such a cycle. The steady, long-term advance of Alaskan tide-water glaciers under favourable mass-balance conditions can thus be contrasted with the rapid, ephemeral advance of Svalbard tide-water glaciers resulting from mass redistribution in the active phase of a surge. Steady advance is facilitated by the maintenance of a moraine shoal, which reduces calving at the tide-water terminus; the shoal advances with the glacier by eroding on the proximal side and redepositing on the distal side (Meier and others, 1978; Trabant and others, 1991). In the Svalbard cases examined here, advance is more rapid, with considerable calving, and, accordingly, the prominent submarine surge moraine associated with Bråsvellbreen, for instance, is formed by rapid ploughing forward of sediments (Solheim, 1991).

\section{SUMMARY}

Simple quantitative analysis of the orientation of recently formed crevasses provides a means of assessing the tectonic effects of a glacier surge at a bulk scale. Both long-term wholesale shifts in stress regime and short-term propagation features have been identified in examples from Svalbard. The position of the surge front relative to the low effective-pressure zone at the terminus of a tidewater glacier may determine the overall rate of terminus advance. In the cases considered here, this low effectivepressure zone is spatially restricted, so the presence of a zone of compression up-glacier is not precluded. Nevertheless, it allows the terminus to be pushed along by the surging ice up-glacier and, further, the rate of terminus advance may significantly increase when the surging ice itself reaches this low effective-pressure zone. The advance of tide-water glacier termini is of particular interest because of the possibility of production of large numbers of icebergs, alterations to fjord morphology and changes in the surface profile, and hence balance conditions, of the large ice caps they often drain.

\section{AGKNOWLEDGEMENTS}

The authors are grateful to the staff of the Norsk Polarinstitutt, Oslo, for access to their comprehensive collection of aerial photographs of Svalbard, and for permission to reproduce the photographs in Figure 5. M.J. Sharp and K.A. Echelmeyer made valuable comments on the original draft. R.H. acknowledges support from a U.K. Natural Environment Research Council research studentship. This work is a contribution to the EC Environment Programme (EN5V-CT93-0299).

\section{REFERENCES}

Dowdeswell, J.A. 1984. Remote sensing studies of Svalbard glaciers. (Ph.D. thesis, University of Cambridge.)

Dowdeswell, J. A. and R. L. Collin. 1990. Fast-flowing outlet glaciers on Svalbard ice caps. Geology, 18, 778-781.

Dowdeswell, J. A., G. S. Hamilton and J. O. Hagen. 1991. The duration of the active phase on surge-type glaciers: contrasts between Svalbard and other regions. F. Glaciol., 37(127), 388-400.

Hagen, J. O., O. M. Korsen and G. Vatne. 1991. Drainage pattern in a subpolar glacier: Brøggerbreen, Svalbard. In Gjessing, Y., J.O. Hagen, K. A. Hassel, K. Sand and B. Wold, eds. Arctic hydrology. Present and future tasks. Oslo, Norwegian National Committee for Hydrology. (Report 23.)

Hagen, J. O., O. Liestøl, E. Roland and T. Jørgensen. 1993. Glacier atlas of Svalbard and Jan Mayen. Nor. Polarinst. Med. 129.

Hambrey M.J. and F.Müller. 1978. Structures and ice deformation in the White Glacier, Axel Heiberg Island, Northwest Territories, Canada. 7. Glaciol., 20(82), 41-66.

Kamb, W.B. and 7 others. 1985. Glacier surge mechanism: 1982-1983 surge of Variegated Glacier, Alaska. Science, 227(4686), 469-479.

Lawson, W. 1989. The structural evolution of Variegated Glacier, Alaska. (Ph.D. thesis, University of Cambridge.)

Liestøl, O. 1972. Glaciological work in 1970. Nor. Polarinst. Arbok 1970, 240-251.

Liestøl, O. 1973. Glaciological work in 1971. Nor. Polarinst. Arbok 1971, $67-75$.

Liestøl, O. 1993. Glaciers of Svalbard, Norway. U.S. Geol. Surv. Prof. Pap. 1386-E-5.

Meier, M.F. 1958. The mechanics of crevasse formation. International Association of Scientific Hydrology Publication 46 (General Assembly of Toronto 1957-Snow and Ice), 500-509.

Meier, M. F. and A. Post. 1987. Fast tidewater glaciers. F. Geophys. Res., 92(B9), 9051-9058.

Meier, M.F. and 9 others. 1978. Columbia Glacier progress report, December 1977. U.S. Geol. Surv. Open File Rep. 78-264.

Nye, J. F. 1952. The mechanics of glacier flow. F. Glaciol., 2(12), 82-93.

Ødegård, R. S., S. -E. Hamran, P.H. Bø, B. Etzelmüller, G. Vatne and J.L. Sollid. 1992. Thermal regime of a valley glacier, Erikbreen, northern Spitsbergen. Polar Res., 11(2), 69-79.

Paterson, W. S. B. 1981. The physics of glaciers. Second edition. Oxford, etc., Pergamon Press.

Pelto, M.S., S.M. Higgins, T.J. Hughes and J.L. Fastook. 1990. Modeling mass-balance changes during a glaciation cycle. Ann. Glaciol., 14, 238-241.

Pfeffer, W.T. 1987. Structure and deformation in a propagating surge front. (Ph.D. thesis, University of Washington.)

Raymond, C.F., T. Johannesson, T. Pfeffer and M. Sharp. 1987. Propagation of a glacier surge into stagnant ice. 7. Geophys. Res., 92(B9), 9037-9049.

Sharp, M.., W. Lawson and R.S. Anderson. 1988. Tectonic processes in a surge-type glacier. J. Struct. Geol., 10(5), 499-515.

Solheim, A. 1991. The depositional environment of surging sub-polar tidewater glaciers; a case study of the morphology, sedimentation and sediment properties in a surge- affected marine basin outside Nordaustlandet, northern Barents Sea. Nor. Polarinst. Skr. 194.

Sturm, M., D. K. Hall, C. S. Benson and W. O. Field. 1991. Nonclimatic control of glacier- terminus fluctuations in the Wrangell and Chugach Mountains, Alaska, U.S.A. J. Glaciol., 37(127), 348-356.

Trabant, D. C., R.M. Krimmel and A. Post. 1991. A preliminary forecast of the advance of Hubbard Glacier and its influence on Russel Fjord, Alaska. U.S. Geol. Surv. Water-Resources Investigations Rep. 90-4172.

The accuracy of references in the text and in this list is the responsibility of the authors, to whom queries should be addressed. 